CASSOWARY - Volume 1 (2): 89 - 94

ISSN : 2614-8900

E-ISSN : 2622-6545

CProgram Pascasarjana Universitas Papua, https://pasca.unipa.ac.id/

\title{
Kontribusi satwa dalam menunjang ketahanan pangan masyarakat Distrik Tembuni Kabupaten Teluk Bintuni
}

\section{Contribution of wild animals in support of public food security in Tembuni District, Teluk Bintuni}

\author{
Iriansul $^{1)}$, Irba A. Warsono ${ }^{2)}$, M. Jen Wajo ${ }^{2{ }^{*}}$
}

1)Dinas Peternakan dan Kesehatan Hewan Provinsi Papua Barat

Jalan Abraham O. Atururi, Arfai, Manokwari, Kodepos 98315, Papua Barat Indonesia

2) Jurusan Produksi Ternak Fakultas Peternakan UNIPA

Jalan Gunung Salju Amban, Manokwari, Kodepos 98314, Papua Barat, Indonesia

*Email: m.wajo@unipa.ac.id

\begin{abstract}
The biodiversity of wild animals in the Tembuni District has the potential of fulfilling nutrition and the economy for the community, but the condition of the area which is still constrained by limited access and still using traditional hunting techniques which influences the level of public consumption of wild animal. This condition has an influence on the pattern of consumption and food security, most of the people of the world. This study aims to identify the description of the region, the characteristics of the population and the potential of hunted animals used by the 4 villages in Tembuni District, namely Bangun Mulya, Mogoi Baru, Tembuni and Araisum villages, so that it can be seen a general description of the area, hunting patterns and techniques 4 villages. It is recognized that the problem of meeting the needs of animal food is used as a policy direction and solution so that it can become information related to the level of consumption of animals but still prioritizes sustainable use to increase the added value of hunting resources and realize food security from animals.
\end{abstract}

Keywords : Food Security, Animal Potential, Animal Consumption

ABSTRAK : Keanekaragaman hayati satwa liar di Distrik Tembuni memiliki potensi pemenuhan gizi maupun ekonomi bagi masyarakat sekitar, namun kondisi daerah yang masih terkendala oleh akses yang terbatas serta masih menggunakan teknik tradisional dalam berburu mempengaruhi tingkat konsumsi masyarakat terhadap satwa liar. Kondisi ini memiliki pengaruh terhadap pola konsumsi dan ketahanan pangan sebagian besar masyarakat tembuni. Penelitian ini bertujuan mengidentifikasi gambaran wilayah, karakteritik penduduk dan potensi satwa buruan yang dimanfaatkan oleh masyarakat 4 kampung di Distrik Tembuni yaitu Kampung Bangun Mulya, Mogoi Baru, Tembuni dan Araisum, sehingga dapat diketahui gambaran umum wilayah, pola dan teknik berburu serta kondisi ketahanan pangan masyarakat 4 kampung. Diketahuinya permasalahan pemenuhan kebutuhan pangan hewani yang digunakan sebagai arahan kebijakan dan solusi sehingga dapat menjadi informasi terkait tingkat konsumsi satwa namun tetap mengutamakan pemanfaatan yang lestari guna meningkatkan nilai tambah sumberdaya buruan dan mewujudkan ketahanan pangan asal hewan.

Kata kunci : Ketahanan Pangan, Potensi Satwa, Konsumsi Satwa 


\section{PENDAHULUAN}

Kekayaan satwa liar di Distrik Tembuni merupakan potensi pemenuhan gizi dan memanfaatkan keanekaragaman hayati. Terdapat beberapa masalah yang membatasi akses masyarakat terhadap potensi sumber protein hewani asal ternak di daerah-daerah sekitarnya, seperti misalnya dari aksesibilitas, kendala teknis, budaya, pemetaan potensi dan lain sebagainya yang menjadikan potensi satwa belum terkelola ataupun terjaga dengan baik.

Permasalahan ini memiliki pengaruh terhadap kondisi ketahanan pangan, termasuk sebagian besar masyarakat di Distrik Tembuni Kabupaten Teluk Bintuni. Sebagian besar masyarakatnya melakukan perburuan satwa, selain untuk memenuhi kebutuhan konsumsi juga sebagian ada yang dijual untuk memenuhi kebutuhan lain. Hal ini disebabkan terutama oleh faktor geografis yang menyebapkan aksesabilitas untuk memperoleh asupan protein ternak sangat rendah. Berdasarkan masalah tersebut diatas maka perlu dikaji tentang tingkat konsumsi satwa sebagai sumber protein hewani sebagai sumber daya buruan yang dapat memberikan nilai tambah untuk mewujudkan keamanan dan ketahanan pangan serta diversifikasi pangan sesuai program pemerintah.

\section{METODE PENELITIAN}

\section{Waktu dan Tempat}

Penelitian ini dilaksanakan di

Distrik Tembuni Kabupaten Teluk Bintuni Maret sampai dengan April 2018.

\section{Materi Penelitian}

Obyek penelitian adalah masyarakat di Distrik Tembuni yang melakukan perburuan dan mengkonsumsi satwa liar. Peralatan yang digunakan dalam penelitian ini adalah kuisioner, alat tulis menulis, timbangan, alat dokumentasi dan Global Positioning System (GPS).

\section{Teknik Pengambilan Sampel}

Metode yang digunakan dalam penelitian ini adalah metode deskriptif dengan teknik studi kasus, dimana yang menjadi kasus dalam penelitian ini adalah pemanfaatan satwa oleh masyarakat di Distrik Tembuni Kabupaten Teluk Bintuni Teknik pengambilan sampel dalam penelitian ini dilakukan dengan metode Teknik sampling snowball adalah suatu metode untuk mengidentifikasi, memilih dan mengambil sampel dalam suatu jaringan atau rantai hubungan yang menerus.

Peneliti menyajikan suatu jaringan melalui gambar sociogram berupa gambar lingkaran-lingkaran yang dikaitkan atau dihubungkan dengan garisgaris. Setiap lingkaran mewakili satu responden atau kasus, dan garis-garis menunjukkan hubungan antar responden atau antar kasus (Neuman, 2003).

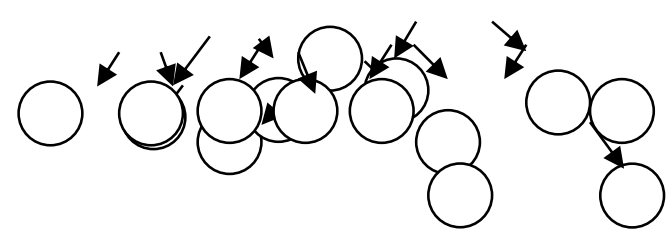

Gambar 1.Teknik sampling snowball

\section{Analisis Data}

Data yang di peroleh di tabulasikan dan di amati utuk memperoleh nilai-nilai rata-rata, model dan analisis NBM. Selanjutnya data-data disajikan dalam bentuk tabel, grafik, foto/gambar.

\section{HASIL DAN PEMBAHSAN}

\section{Jenis Satwa yang diburu}

Jenis satwa yang diburu oleh masyarakat beragam dan disesuaikan dengan kebutuhan konsumsi keluarga. Data jenis satwa yang diburu masyarakat di Distrik Tembuni. 
Tabel 1. Jumlah dan jenis satwa yang diburu di Distrik Tembuni

\begin{tabular}{|c|c|c|c|c|c|c|c|c|c|}
\hline \multirow[b]{2}{*}{ Nama Kampung } & \multicolumn{9}{|c|}{ Jenis Satwa (Ekor) } \\
\hline & $\underset{\mathscr{N}}{\stackrel{\tilde{N}}{\mathcal{\alpha}}}$ & 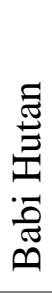 & 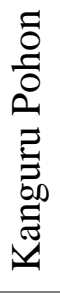 & 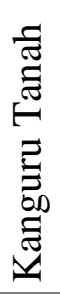 & $\begin{array}{l}\text { 光 } \\
\text { 营 }\end{array}$ & 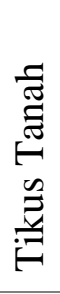 & 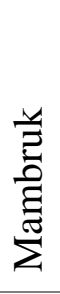 & $\frac{\stackrel{0}{\frac{d}{\pi}}}{\frac{\pi}{\Sigma}}$ & 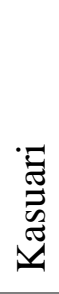 \\
\hline 1.Bangun Mulyo & $\sqrt{ }$ & $\sqrt{ }$ & $\sqrt{ }$ & $\sqrt{ }$ & $\sqrt{ }$ & $\sqrt{ }$ & $\sqrt{ }$ & $\sqrt{ }$ & $\sqrt{ }$ \\
\hline 2.Tembuni & $\sqrt{ }$ & $\sqrt{ }$ & $\sqrt{ }$ & $\sqrt{ }$ & $\sqrt{ }$ & $\sqrt{ }$ & $\sqrt{ }$ & $\sqrt{ }$ & $\sqrt{ }$ \\
\hline 3. Arisum & $\sqrt{ }$ & $\sqrt{ }$ & $\sqrt{ }$ & $\sqrt{ }$ & $\sqrt{ }$ & $\sqrt{ }$ & $\sqrt{ }$ & $\sqrt{ }$ & $\sqrt{ }$ \\
\hline 4. Mogoi Baru & $\sqrt{ }$ & $\sqrt{ }$ & $\sqrt{ }$ & $\sqrt{ }$ & $\sqrt{ }$ & $\sqrt{ }$ & $\sqrt{ }$ & $\sqrt{ }$ & $\sqrt{ }$ \\
\hline
\end{tabular}

Keterangan: $\sqrt{ }=\mathbf{a d a}$

Tabel 2. Habitat hidup satwa (utama) di Distrik Tembuni Kabuapaten Teluk Bintuni

\begin{tabular}{lccccccc}
\hline Nama & \multicolumn{7}{c}{ Habitat Hidup Satwa (utama) } \\
\cline { 2 - 8 } & $\begin{array}{c}\text { Sungai } \\
\text { Wasian }\end{array}$ & $\begin{array}{c}\text { Kali } \\
\text { Dudida }\end{array}$ & $\begin{array}{c}\text { Kali } \\
\text { Sebian }\end{array}$ & Membra & Manopi & $\begin{array}{c}\text { Sumur } \\
17\end{array}$ & $\begin{array}{c}\text { Sumur } \\
85\end{array}$ \\
\hline $\begin{array}{l}\text { 1.Bangun } \\
\text { Mulyo }\end{array}$ & 5 & 0 & 0 & 4 & 2 & 2 & 1 \\
$\begin{array}{l}\text { 2. Tembuni } \\
\text { 3. Arisum }\end{array}$ & 11 & 1 & 1 & 0 & 0 & 0 & 0 \\
$\begin{array}{l}\text { 4.Mogoi } \\
\quad \text { Baru }\end{array}$ & 6 & 0 & 0 & 0 & 0 & 0 & 0 \\
\hline Jumlah & 30 & 0 & 0 & 0 & 0 & 0 & 0 \\
Nisbah (\%) & 73,17 & 2,44 & 2,44 & 9,76 & 4,88 & 4,88 & 2,44 \\
\hline
\end{tabular}

Data pada Tabel 1. menunjukkan bahwa, jenis satwa yang diburu untuk konsumsi dan sumber pendapatan masyarakat di Distrik Tembuni terdapat 9 jenis, yaitu rusa, babi hutan, kanguru pohon, kanguru tanah, ular, biawak (soasoa), tikus tanah, burung mambruk, burung maleo, burung kasuari, Hasil pengamatan dan wawancara dengan responden, diketahui bahwa semua kampung memiliki kesamaan jenis satwa yang diburu untuk tujuan konsumsi dan sumber pendapatan (dijual).

\section{Habitat Tempat Hidup Satwa}

Habitat tempat satwa hidup adalah didalam kawasan hutan disekitar kampung yang berada di Distrik Tembuni, sehingga masyarakat harus masuk kedalam hutan untuk berburu. Berdasa- kan habitat terdapat lokasi utama tempat habitat hidup satwa sebagai lokasi perburuan, seperti disajikan dalam Tabel 2.

Data pada Tabel 12. Menunjukkan bahwa, lokasi utama tempat hidup atau habitat satwa sebagai hewan buruan masyarakat di Distrik Tembuni, diketahui 30 orang responden atau $73,17 \%$ mengatakan habitat utama satwa adalah di sepanjang aliran Sungai Wasian di karenakan sungai wasian melintasi Distrik Tembuni hampir semua kampung di tembuni berada di sepanjang aliran sungai wasian seperti di tampilkan pada lampiran 1 peta wilayah berburu sedangkan pecahan sungai wasian membentuk kali kecil disebut Kali Dudida dan Kali Sebian, hal ini berdasarkan pengakuan dari 2 orang responden atau 4,88\%, Membran, Manopi, Sumur 85 
dan disekitar sumur 17 adalah bekas sumur pengeboran minyak yang sudah tidak di gunakan lagi sedangkan ambalat adalah daerah bekas perusahaan kayu yang sudah tidak ada aktifitas penebangan kayu.

\section{Nilai Ketahan pangan Satwa Buruan}

Bahan pangan daging satwa buruan yang siap dikonsumsi masyarakat, setelah jumlah produksi daging ditambah impor dikurangi dengan penjualan (eksport), tercecer (5\% dari produksi), maka didapat data seperti di tampilkan dalam Tabel 3.

Jumlah daging satwa rusa dan babi yang di konsumsi masyarakat selama satu tahun di 4 (empat) kampung sasaran penelitian sebanyak $43.419 \mathrm{Kg}$, perhitungannya sudah mengurangi dengan jual dan tercecer. Tidak ada bahan pangan hewani asal satwa yang dibeli masyarakat dari luar untuk di konsumsi, sehingga nilai impor tidak ada atau nol. Selanjutnya data konsumsi di konversikan untuk mengatahui tingkat konsumsi per kapita per tahun $(\mathrm{Kg})$ dan tingkat konsumsi protein per kapita per tahun dari 4 (empat) kampung sasaran penelitian.

\section{Tingkat Konsumsi Per Kapita}

Tingkat konsumsi per kapita merupakan kelanjutan perhitungan dari tingkat konsumsi yang dibagi habis dengan jumlah jiwa dalam satu daerah. Hasil pengumpulan data di 4 (empat) kampung sasaran penelitian dan 6 (enam) dusun, diketahui ada 913 orang (jiwa) dari 229 Rumah Tangga (RT) di Distrik Tembuni. Data tingkat konsumsi per kapita selengkapnya, disajikan dalam Tabel 4.

Tabel 3. Konsumsi daging satwa di Distrik Tembuni

\begin{tabular}{|c|c|c|c|c|c|c|}
\hline Kampung & $\begin{array}{c}\text { Produksi } \\
\text { (Keluaran/ } \\
\text { Kg) } \\
(2)\end{array}$ & $\begin{array}{l}\text { Impor } \\
\text { (Beli) }\end{array}$ & $\begin{array}{c}\text { Ekspor } \\
\text { (Jual) }\end{array}$ & Ketersediaan & $\begin{array}{l}\text { Tercecer } \\
\quad(5 \%) \\
(6)=(2) x(5 \%)\end{array}$ & $\begin{array}{c}\text { Bama Siap } \\
\text { di Konsumsi } \\
\text { (Kg/Tahun) } \\
(7)=(5)-(6)\end{array}$ \\
\hline B. Mulyo & 35.456 & 0 & 17.515 & 17.941 & 1.368 & 8.477 \\
\hline Tembuni & 32.101 & 0 & 14.760 & 17.341 & 1.870 & 15.471 \\
\hline Arisum & 27.348 & 0 & 15.132 & 12.216 & 1.587 & 10.629 \\
\hline Mogoi Baru & 19.797 & 0 & 9.789 & 10.008 & 1.167 & 8.842 \\
\hline Jumlah & 114.703 & 0 & 57.196 & 57.506 & 5.991 & 43.419 \\
\hline
\end{tabular}

Tabel 4. Tingkat Konsumsi Per Kapita

\begin{tabular}{lcccc}
\hline Kampung & $\begin{array}{c}\text { Bama Siap } \\
\text { di Konsumsi }\end{array}$ & \multicolumn{2}{c}{ Konsumsi Pangan } & $\begin{array}{c}\text { Tingkat Konsumsi } \\
\text { Protein }\end{array}$ \\
\hline & (Kg/Tahun $)$ & (Kg/Kapita/Tahun $)$ & $($ Gr/Kapita/Hari $)$ & $($ Gr/Kapita/Hari $)$ \\
\hline \multicolumn{1}{c}{$(1)$} & $(2)$ & $(3)=(2) / 913$ & $(4)=(3) * 1000 / 365)$ & $(5)=(4) *$ BDD*\% Protsatwa) \\
B. Mulyo & 8.477 & 9,28 & 25,44 & 4,62 \\
Tembuni & 15.471 & 16,95 & 46,43 & 8,45 \\
Arisum & 10.629 & 11,64 & 31,90 & 5,81 \\
Mogoi Baru & 8.842 & 9,68 & 26,53 & 4,83 \\
Jumlah & 43.419 & 47.56 & 225,69 & 23,71 \\
Rata-rata & & & & 5,93 \\
\hline
\end{tabular}


Data tingkat konsumsi protein hewani satwa buruan di Distrik Tembuni seperti dalam Tabel 4 adalah sebesar 5,93 gram per kapita per hari dikatagorikan sudah memenuhi standar yang dianjurkan oleh pemerintah. Hardiansyah (2012) mengutip Angka kecukupan protein yang dianjurkan pemerintah, sesuai hasil Widyakarya Pangan dan Gizi Tahun 2012 adalah 57 gram/kapita/hari dengan porsi untuk protein hewani sebesar $25 \%$ atau 14,25 gr /kapita/hari.

\section{KESIMPULAN}

Potensi sata di Distrik tembuni Masih sangat banyak, yang melakukan perburuan masih sedikit dan teknologi yang digunakan masih sederhana serta tebatasnya akses Berdasarkan nilai protein standar WKPG diatas stadar yang ditentukan dan dari satwa ini meningkatkan pedapatan masyarakat yang melakukan perburuan. Penetapan peraturan secara lestari dengan memanfaatkan kekuatan adat lokal setempat untuk pebatasan waktu, berburu, peralatan berburu, pembatasan jumlah buruan dan pengunaan alat berburu.

\section{DAFTAR PUSTAKA}

Adriani, Merryana dan Wirjatmadi, Bambang. 2012. Pengantar Gizi Masyarakat. Kencana. Jakarta

Andoyo S. dan M. Jen Wajo. 2002. Studi Sifat-sifat Kualitatif dan Kuantitatif Serta Anatomi Fisiologi Kuskus (Phalangger, SP) di Pulau Moor Nabire. Hasil Penelitian Faperta Uncen. Manokwari.

Conservation International, 1999. The Irian Jaya Biodiversity Conservation Priority Setting Workshop. Final Report. Concervation Internatinal, Washington, DC. USA
De Vos , A., 1973. Wildlife Production In Afrika. In: Reid, R.L.(ed) Proceedings Of The 3 rdWorld Conference On Animal Production. Melbourne, Australia.

Dinas Peternakan dan Kesehatan Hewan Provinsi Papua Barat, 2018. Data Statistik Peternakan dan Kesehatan Hewan Tahun 2017. Manokwari.

Farida, W.R., G. Semiadi, Wirdateti, dan H. Dahruddin. 2001. Pemanfaatan kuskus (Phalanger sp.) oleh masyarakat Timor Barat, Nusa Tenggara Timur. Biota 6 (2): $85-86$

Hardiansyah, 2012. Pangan Asal Ternak dan Peranannya dalam Pembangunan Sumber Daya Manusia.

Iriansul, 2007. Pemanfaatan Satwa Liar oleh Masyrakat Hatam- Moile Distrik Tanah Rubuh. Skripsi Sarjana Peternakan Universitas Negeri Papua Manokwari

Kementrian Pertanian, 2016.Statistik Peternakan Dan Kesehatan Hewan 2016, Jakarta : Direktorat Jenderal Peternakan dan Kesehatan Hewan

Kusrini, S.D., 2001. Tingkat Konsumsi Daging Bandikut Oleh Penduduk Asli Dan Faktor-Faktor Yang Mempengaruhinya Di Kecamatan Warmare .Skripsi Sarjana Peternakan Faperta Uncen Manokwari

Maipita Indra, 2014. Mengukur Kemiskinan dan Distribusi Pendapatan Edisi I. Penerbit UPP STIM YKPN. Yogyakarta.

Nainggolan, Kaman. 2008. "Ketahanan dan Stabilitas Pasokan, Permintaan dan Harga Komoditas Pangan". Analisis Kebijakan Pertanian. Volume 6 No. 2 bulan Juni 2008. Hal. 114 - 139.

Neuman, W.Lawrence. 2003. Social Research Methods: Qualitative 
And Quantitative Approaches. Boston : Allyn and Bacon.

Pattiselanno, F dan Mentasan, G., 2010. Kearifan Tradisional Suku Maybrat dalam PerburuanSatwa sebagai Penunjang Pelestarian Satwa.Makara-Sosial Humaniora, 14(2):75-82.

Pattiselanno, F., 2005. Traditional Hunting For Sustainable Wildlife Management (Current Review On Wildlife Hunting In West Papua). The Seventh New Guinea Biological Conference Jayapura, Indonesia, Juni 16-18 2005

Pattiselanno, F., 2006. The Wildlife Hunting In Papua. Biota Vol XI (1):59- 61

Peraturan Pemerintah Nomor 18 tahun 2011.Tentang Kedaulatan Pangan dan Ketahanan Pangan : Sekretariat Negara jakarta.

Peraturan Pemerintah Nomor 28 tahun 2004.Tentang Keamanan,Mutu dan Gizi Pangan : Sekretariat Negara jakarta.

Peraturan Pemerintah Nomor 68 tahun 2002.Tentang Penganekaragaman Pangan : Sekretariat Negara jakarta.

Rahawarin .Y. Y, Kilmaskossu.V,Y. Kerepea, Mofu. W.Y.,Angrianto. R, Peday. F. Z.H,. Sinery .S.A dan Dimara A.P..2014. perburuan kasuari (Casuarius spp.) Secara Tradisional Oleh Masyarakat Suku Nduga Di Distrik Sawaerma Kabupaten Asmat J. Manusia dan Lingkungan, Vol. 21, No.1, Maret. 2014: 98-105

Saroyo , 2010.Konsumsi Mamalia, Burung, Dan Reptil Liar Pada Masyarakat Sulawesi Utara Dan Aspek Konsevasi. Jurnal biologos. Agustus 2011. Vol.1.No.1
Semiadi, G. 2007. Pemanfaatan Satwa Liar Dalam Rangka Konservasi Dan Pemenuhan Gizi Masyarakat. Zoo Indonesia 16: $63-74$.

Siregar, Z. 2009. Pemanfaatan Hasil

Samping Perkebunan Dengan Penambahan Mineral Dan Hidrolisat Bulu Ayam. Pidato Pengukuhan Jabatan Guru Besar Tetap dalam Bidang Ilmu Mikrobiologi Nutrisi Universitas Sumatera Utara Medan

Suhardjo. 1989. Sosio Budaya Gizi. Bogor : Departemen Pendidikan dan Kebudayaan Direktorat Jendral Pendidikan tinggi pusat antar universitas pangan dan gizi. Institut Pertanian Bogor.

Wajo, M. J. 1998. Studi Potensi dan Morfologi Burung Kasuari (Casuarius casuarius). Hasil Penelitian Fapera Uncen. Manokwari

Warsono,U.I. 2009 .Sifat Biologis Dan Karakteristik Karkas Dan Daging Bandikut (Echymipera Kalubu). Diesertasi Sekolah Pasca sarjana Institut Pertanian Bogor.Bogor 2009.

Wasaraka Y.N.K.,.2011.Pola Konsumsi Pangan Masyarakat Papua (Studi Kasus Di Kampung Tablanusu, Distrik Depapre, Kabupaten Jayapura, Provinsi Papua). Skripsi Sarjana Gisi Fakultas Ekologi Manusia Institut Pertanian Bogor. 